\title{
A DESCRIPTIVE STUDY ON E-GOVERNANCE
}

\author{
C Balaji Viswanath \\ Research Scholar, Madurai Kamaraj University, Madurai
}

\begin{abstract}
The true concept of democracy includes the participation of individuals in the governing process. But due to gargantuan population the active participation of citizen in governing process is not possible. But egovernance makes it possible through online feedback system from the public. This paper entirely deals with the concept of e-governance and the application of e-governance in various domains. The role of information and communication technology [ICT] in e-governance, the scope \& objective of e-governance. The scope includes four main aspect namely G2C; C2G; G2B; G2G.Finally this paper includes the overview of Digital India project, e-governance plan formulated by the government and our views.
\end{abstract}

\section{KEYWORDS}

e-governance; G2C; $C 2 G$; G2B; G2G; national e-governance plan; Digital India

\section{INTRODUCTION}

E-Governance, a most recent technological tool has become a necessary concern of primary importance for industries and corporate of national and international level. The economy of the country depends on the performance of industries and corporate against the international competitiveness.

Comprehensive information forms the basis of any company performance, when the information become application oriented the technical information step in and e-governance is the final off shoot of the Information Technology development. In order to with stand the international competition the use of e-governance has become inevitable

The term 'Governance' is extended version of 'Government'. Governance may be an activity of controlling a country by its Government. Accordingly E-governance may also involve governing a country with the help of Information and Communication Technology (ICT).E-governance therefore means the application of ICT to exchange a information in an effectual manner. Information Technology has both it's merits and demerits while implementing e-governance, the negative aspect of IT like Hacking the website, cracking the data has to be addressed properly [1].

\section{OBJECTIVES OF E-GOVERNANCE}

Following are the objectives/aims of E-Governance:

$>$ To fabricate an interactive society - To empower the society, the people must be updated on all current policies of government. In order to attain it they must be well informed. This mission can be achieved through e-governance. 
$>$ To bolster citizen participation - The core value of democracy is "for the people, of the people, by the people". The augmented population has led to representative democracy, which is not democracy in the true sense. E-governance aims to restore democracy to its true meaning by improving citizen participation in the Governing process, by improving the feedback, access to information.

To bring lucidity in the governing process - The root cause of corruption is back the screen activities which are not known to common man. E-governance carries an objective to make the Governing process transparent by making all the Government data and information available to the people for access. It is to make people know the decisions, and policies of the Government. if e-governance is executed in full stretch all data's can be made publicly available Ex: Auction of government project can be made online so that transparency can be attained moreover the public money can be properly utilized.

$>$ To enhance Government accountability - For every decision taken with respect to government policies, the government authorities must be made accountable, they should not getaway through the loop holes. Since e-governance makes the citizen more informative they will be more aware of what is happening in and around them. E-Governance aims to make the Government more accountable by bringing transparency.

To alleviate the cost and reaction time - By curtailing the expense on physical delivery of information and services, we can reach the public in short span of time to fulfill their requirement. Similarly the grievances of public can be settled within limited duration through e-governance. This is possible because of advancement in information technology

\section{SCOPE OF E-GOVERNANCE}

The flow of information between the Government and Citizens, Government and Businesses and Government and Government is referred to as Governance. E-Governance also covers all these relationships as follows:
A. Government to Citizen (G2C)
B. Citizen to Government (C2G)
C. Government to Government $(\mathrm{G} 2 \mathrm{G})$
D. Government to Business (G2B)

\section{1.Government to Citizen}

The most basic aspect of E-Governance is cordial relationship between Government and Citizen. In current scenario, Government deals with many aspects of the life of a citizen. The nexus of a citizen with the Government starts with the birth and ends with the death of the citizen.

The G2C relation will include the services provided by the Government to the Citizens. These services include the public utility services like Transportation, Education, Medical facilities, etc. 
E-Citizenship - E-Citizenship involves online transactions relating to issue and renewal of documents like Ration Cards, Passports, Election Cards, Identity Cards, etc. A virtual identity of every citizen will be created so as to enable them to access the Government services online, moreover duplication will be shun and service will be delivered to right person. In turn Government would need to create a Citizen Database which is a mammoth task.

E-Registration - E-registration will help to reduce a significant amount of paperwork. This will cover the online registration of various contracts.

E-Transportation - E-Transportation services would include ICT enablement of services of Government relating to Transport by Road, Rail, Water or Air. This may involve online:

1. Booking and cancellation of tickets,

2. Status of vehicles, railways, boats and flights,

3. Payment of fees and taxes for vehicle registration.

D-Health - E-Health services would be ICT enablement of the health services of the Government. Recently the government of Tamilnadu has launched free help line number for "Medical Emergency -104" which is available around the clock. Under this interconnection of all hospitals may take place. A patient database may be created. A local pharmacy database may also be created. The next version can be reminding the patient regarding the periodically check up.

D-Help - E-Help refers to general help line number. It includes the use of technologies like internet, SMS, etc. for the purpose of reducing the response time of the Government agencies to the people queries and at the time of disasters. Recently on 19.1.16 the government of Tamilnadu has launched "Amma Call Center-1100", "Women Help line number - 1091", “Child Help Line Number -1098" The role of NGOs is also vital in helping the Government during the time of disasters. in order to connect with disaster affected people the government has launched "Disaster Toll Free Number 1070"

E-Taxation - E-Taxation will facilitate payment of tax through online. Online tax due alerts will be a better app for common man so that they stay in touch with government. Income Tax return can be filed online.

\subsection{Citizen to Government}

Citizen to Government relationship will include the communication of citizens with the Government arising in the Democratic process like voting, feedback, etc.

$>$ E-Feedback - E-Feedback includes the use of Information Technology for the purpose of giving feedback to the Government. Ex: Recently for the purpose of implementing smart city project the government is open to public opinion through online feedback

\subsection{Government to Government}

G2G relationship would include the relationships between Central and State Government and also the relationship between two or more Government departments. 
> E-administration - E-administration would include the implementation of IT in the functioning of the Government, internally and externally. E-administration can substantially reduce paperwork if properly used. E-administration will also bring morality and transparency to the administration of Government Departments.

D E-police - The concept of E-police includes databases of Police Officers, their performances, Criminal databases. This is little different from Cyber-Police. Cyber Police require technology experts to curb the electronic crimes. Whereas e-police inclined to reduce the response time of police department when approached by public.

E-courts - The concept of E-Court will include the IT enablement of the judicial process. This will ultimately decrease the time delay in hearing a case. Details regarding the cases can be seen online, even though it's there in current scenario but it's not effectively followed. Government must see the ways and means through which this can be implemented effectively

\subsection{Government to Business}

$>$ E-Licensing - Companies have to acquire various licenses from the Government. If this procedures are effectively followed in online, time duration can be reduced

$>$ E-Tendering-E-Tendering will include the facilities of online tendering and procurement. If submission of tenders and allotment of work is made online. It will reduce time and cost involved in the physical tendering system. Moreover the scams like coal scam, spectrum scam can be averted, since online tendering is made public, third party will not be entertained in the auction. [2]

\section{STAGES OF E-GOVERNANCE}

United Nations E-Readiness Survey contemplates the following stages of E-governance as to the online presence of Governments worldwide:

Emerging Presence - The Stage I considers online availability of limited and basic information. A basic online presence of an e-government involves an official website and few WebPages. Links to ministries and departments of Central Government, regional/local Government may or may not be available. Ex: District Websites

Enhanced presence - The Stage II contemplated by UN is Enhanced presence of the Government online. At this stage the Government provides more public information resources such as policies of the Government, laws, regulations, reports, newsletters. This may also be downloadable at this stage. This stage may allow users to search the information within the documents available online. There is no interactivity at this stage as the information is only flowing towards the citizens rather than also from citizens to Government.

Interactive presence - The Stage III of Interactive presence considers Governments to initiate interactivity in their websites. It involves availability of online services of the government to enhance convenience of the consumer. This will include downloadable forms and applications for payment of bills, taxes and renewal of licenses. Government Websites at this stage would have audio and video capability to increase the interactivity with the citizens. At this stage the government officials would be able contacted via email, fax, telephone and post. The website 
would be updated regularly to keep the information current and up to date for the public. Ex: Pensioners Form, e-filing of Income Tax, Allocation of Industrial Space form

Transactional presence - The Stage IV i.e. transactional presence allows two-way interaction between the citizens and Government. It includes options such as paying taxes, applying for ID cards, birth certificates, passports, license renewals and other similar $\mathrm{C} 2 \mathrm{G}$ interactions by allowing the citizen to submit forms and applications online 24/7. Providers of goods and services are able to bid online for public contacts via secure links.

Networked presence - The Stage V as contemplated by UN Survey is 'Networked Presence' which represents the most sophisticated level in the online e-government initiatives. It can be characterized by an integration of G2G, G2C and C2G interactions. The government at this stage encourages citizen participation, online participatory decision-making and is willing and able to involve the society in a two-way open dialogue [3].

\section{STRATEGIES FOR E-GOVERNANCE IN INDIA}

\subsection{To build technical infrastructure across India}

Since India lacks a full fledged Information Technology framework for implementation of egovernance. Complete implementation of E-governance in India will include building technical Hardware and Software infrastructure. The infrastructure must be built by PPP [Public Private Partnership]. With regard to this PPP policy 2011 has been formulated Infrastructure will also include promotion of Internet Cafes, Information and Interactive Kiosks.

\subsection{To build institutional capacity}

Apart from building technical infrastructure, the Government needs to build its institutional capacity. This will include training of Government employees, appointment of experts. Apart from this, the Government has to modernize the departments with hi-fi technology.

\subsection{To build legal infrastructure}

Changing technology has changed many pre-established notions. It is imperative that the Government frame laws which incorporate the current technology and has enough space to incorporate the changing future technology. The current IT laws need to be flexible to adjust with the rapidly changing technology. Currently India has only the IT Act, 2000 which is mainly an ECommerce legislation. However it is not sufficient to cover e-governance completely with the current legal formalities, since it doesn't address the problematic issues of information technologies properly.

\subsection{To build judicial infrastructure}

The judiciary as a whole needs to be trained in new technology, its benefits and drawbacks and the various usages. The judiciary may alternatively appoint new judges and setup special Courts to deal with the matters relating to ICT. The Government can also setup special tribunals to deal with matters relating with Information Communication Technology. The officials must be properly trained in latest technology; so that they can tackle IT related cases without any bewilderment 


\subsection{To make all information available online}

The Government has to publish all the information online through websites. This can be facilitated through centralized storage of information. The information of government is public information; therefore the citizens are entitled to know every piece of information of the Government, because the Government is of the People, by the People and for the People which is the core value of democracy.

\subsection{To set standards}

Finally it is important to set various standards to bring e-governance to the quality and performance level of private corporate sector. The Government of India is currently working on standards management and has various drafts prepared for the same. These standards include following:

$>$ Inter-operability standards,

$>$ Security standards,

Technical and Quality standards

Government websites in India currently have no uniform standard. It is very important for the Government to set uniform national standards to be followed by all the Government department[4].

\section{National E-Governance Plan}

Over the years, a large number of initiatives have been undertaken by various Governments to usher in an era of e-Government. Sustained efforts have been made at multiple levels to improve the delivery of public services and simplify the process of accessing them.

The National e-Governance Plan (NeGP), takes a holistic view of e-Governance initiatives across the country, integrating them into a collective vision, a shared cause. Around this idea, a massive countrywide infrastructure reaching down to the remotest of villages is evolving, and large-scale digitization of records is taking place to enable easy, reliable access over the internet. The ultimate objective is to bring public services closer home to citizens, as articulated in the vision statement of NeGP

\section{Vision Statement of NeGP}

"Make all Government services accessible to the common man in his locality, through common service delivery outlets, and ensure efficiency, transparency, and reliability of such services at affordable costs to realize the basic needs of the common man"

The Government approved the National e-Governance Plan (NeGP), comprising of 27 Mission Mode Projects and 8 components, on May 18, 2006. In the year 2011, 4 projects - Health, Education, PDS and Posts were introduced to make the list of 27 MMPs to 31Mission Mode Projects (MMPs). The Government has accorded approval to the vision, approach, strategy, key components, implementation methodology, and management structure for NeGP. 
In order to promote e-Governance in a holistic manner, various policy initiatives and projects have been undertaken to develop core and support infrastructure. The major core infrastructure components are

\section{State Data Centers (SDCs),}

$>$ State Wide Area Networks (S.W.A.N),

$>$ Common Services Centers (CSCs) and

Middleware gateways i.e National e-Governance Service Delivery Gateway (NSDG), State e-Governance Service Delivery Gateway (SSDG), and Mobile eGovernance Service Delivery Gateway (MSDG) [5].

\section{Digital India}

Without discussing "Digital India" project this paper will not be fulfilled, since DI is just an advancement of e-governance or in other words the upgraded version of e-governance. DI is an initiative by the Government of India to ensure that Government services are made available to citizens electronically by improving online infrastructure and by increasing Internet connectivity. It was launched on 1 July 2015 by Prime Minister Narendra Modi. With the launch of this programme the government is taking a big step forward to transform the country into a digitally empowered knowledge economy. The programme includes projects that aim to ensure that government services are available to citizens electronically and people get benefit of the latest information and communication technology.

\section{Vision of Digital India}

$>$ Digital Infrastructure as a utility to every citizen

Services on demand

$>$ Digital Empowerment of citizen

\section{Pillars of DI}

$>$ Universal access to phones

$>$ Broadband highways

> Public internet access programme

\section{Impact of DI in future}

$>$ Broadband in 2.5lakhs villages

$>$ Job creation: Direct $-1.7 \mathrm{cr}$; Indirect atleast -8 crore [6] 


\title{
7.CONCLUSION
}

E-Governance in India has steadily evolved from computerization of Government Departments to encapsulate the finer points of Governance, such as citizen centricity, service orientation and transparency. Lessons from previous e-Governance initiatives have played an important role in shaping the progressive e-Governance strategy of the country. Literacy percentage in India is alarming. The whole world is moving towards e-governance, but India still lacks in the literacy department. The people need to be educated and made e-literate for e-governance to flourish. In our point of view the role of Information and Communication Technology [ICT] in governing a country or an organization is ubiquitous [everywhere]. So the government both central \& state must make this facility much easier for the common man. This will ultimately lead to gradual decrease in corruption. Moreover the government must create awareness to public in utilizing these services. The countries growth is an inclusive one in which e-governance plays a vital role. Since this is the era of information technology e-governance is inevitable. The Government needs to campaign for e-governance, increase people's awareness towards e-governance. Right now the government is on the right track by announcing Digital India, Make in India projects but the thing is that they should keep going without any obstacles, so that we can reach the pinnacle of global economy within short span of time[7].

\section{REFERENCES}

[1] http://indiaegovernance.blogspot.in/2008/03/e-governance-what-does-it-mean.html

[2] http://indiaegovernance.blogspot.in/2008/03/scope-of-e-governance.html

[3] http://indiaegovernance.blogspot.in/2008/04/stages-of-e-governance.html

[4] http://indiaegovernance.blogspot.in/2008/04/strategies-for-e-governance-in-india.html.

[5] http://deity.gov.in/content/national-e-governance-plan

[6] http://www.oneindia.com/feature/what-is-digital-india-programme-explained-1792279.html

[7] Own Comments

\begin{abstract}
Author
The author of this paper Mr.C.Balaji Viswanath is working as an Assistant Professor in the Department of Computer Science and MBA in Subbulakshmi Lakshmipathy College of Science, Madurai. Moreover he is a research scholar in Madurai Kamaraj University. He had completed B.E Computer Science from SRM Valliammai Engineering College, and then he did his post graduation in MBA [Human Resource and Marketing] from Anna University, Chennai. Now he is pursuing his Ph.D from Madurai Kamaraj University in Social Media Marketing Domain. He had attended many national conferences and a state level conference. He has two years of teaching experience.
\end{abstract}

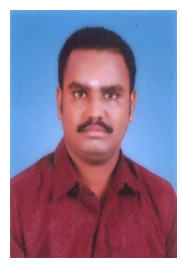

